\title{
Development of a PCR probe test for identifying Pseudomonas aeruginosa and Pseudomonas (Burkholderia) cepacia
}

\author{
E M O'Callaghan, M S Tanner, G J Boulnois
}

\begin{abstract}
Aims-To develop a system of species specific polymerase chain reaction (PCR) and DNA hybridisation based on 16s ribosomal RNA sequences for the identification of Pseudomonas aeruginosa and Pseudomonas (Burkholderia) cepacia in sputum from children with cystic fibrosis.

Methods-Most of the 16s rRNA sequences from strains of $P s$ aeruginosa, Ps (Burkholderia) cepacia, and Ps putida were determined. PCR primers and DNA probes were synthesised from suitable sequences and then evaluated on bacterial cultures and sputum samples.

Results-About 1000 bases of sequence was obtained from strains of $P s$ aeruginosa, Ps (Burkholderia) cepacia, and Ps putida. PCR of bacterial cultures was species specific, but PCR on sputum resulted in some non-specific amplification products. The subsequent hybridisation reaction was species specifc.

Conclusion-A species specific system of PCR and DNA hybridisation based on 16s rRNA sequences is applicable in clinical practice, and may aid the early diagnosis of respiratory tract infection with small numbers of $P s$ aeruginosa and $P s$ (Burkholderia) cepacia in patients with cystic fibrosis.
\end{abstract}

(F Clin Pathol 1994;47:222-226)

In patients with cystic fibrosis chronic colonisation of the respiratory tract by Pseudomonas aeruginosa is followed by a slow decline in their respiratory function. ${ }^{1}$ Antibiotic treatment is associated with a temporary clinical improvement but does not eradicate the organism. It is reasonable to believe that very early detection of $P S$ aeruginosa infection would increase the chances of successful eradication. The presence of increased titres of serum IgA antibodies specific to $P$ s aeruginosa before the organism can be isolated from the sputum using conventional microbiological techniques ${ }^{2}$ suggests that initial infection may be with small numbers of organisms. Chronic infection with Ps aeruginosa, however, can occur without an antibody response, and, conversely, the presence of serum antibodies does not necessarily implicate the lower respiratory tract as the site of infection. To produce a sensitive means of identifying infection with small numbers of $P s$ aeruginosa in the respiratory tract we have developed a system of species specific polymerase chain reaction (PCR) and DNA hybridisation which can be applied directly to sputum samples.

The incidence of infection with Pseudomonas (Burkholderia) cepacia is increasing in patients with cystic fibrosis. The prevalence in the United Kingdom is about $7 \%^{34}$ but in some North American centres it has been reported to be as high as $20 \% .^{5}$ Ps (Burkholderia) cepacia infection presents a major clinical problem both because its acquisition may be associated with a rapid deterioration in the patient's condition and because it is multiply drug resistant. ${ }^{5-7} P_{S}$ (Burkholderia) cepacia tends to grow slowly and with a variable colony morphology on media commonly used for routine sputum culture, and it can therefore be obscured by overgrowth of Ps aeruginosa or confused with other respiratory pathogens, such as Staphylococcus aureus, which have a similar morphological appearance. ${ }^{89}$ Species specific PCR and DNA hybridisation would make it possible to detect and distinguish between infection with either $P s$ aeruginosa or $P s$ (Burkholderia) cepacia directly in sputum.

The nucleotide sequence of $16 \mathrm{~s}$ ribosomal RNA (16s rRNA) has a unique structure with conserved regions common to all bacteria, as well as highly variable regions which are species specific ${ }^{1011}$ and provide an ideal basis for the synthesis of species specific oligonucleotide probes. $^{12}$ rRNA probes have proved useful in diagnosing infections with organisms that are difficult to culture. ${ }^{13}$ rRNA probes, however, are not especially sensitive as they only detect about $10^{3}$ cells $/ \mathrm{ml}^{14}$ even though there are about 10000 copies of rRNA per cell. ${ }^{15}$ This lack of sensitivity can be overcome by using PCR to amplify the amount of DNA and thereby increase the sensitivity of any subsequent hybridisations. Hybridisation of a PCR product with a ${ }^{32} \mathrm{P}$-labelled oligonucleotide can increase sensitivity by a factor of 100 when compared with visualisation of a PCR band on agarose gel electrophoresis. Previous studies have shown that combining the amplification procedure with a slot blot hybridisation resulted in a detection limit of fewer than 10 mycobacterial cells in a sample. ${ }^{1216}$ Other approaches have used PCR primers from conserved regions of the 16s rRNA to amplify the entire gene for $16 \mathrm{~s}$ rRA (16s rDNA) from all bacteria. ${ }^{17}$

We describe here the use of both the 
conserved and the variable regions of the 16s rRNA from $P s$ aeruginosa and $P S$ (Burkholderia) cepacia to develop a system of species specific PCR and oligonucleotide probe hybridisation targeted at the $16 \mathrm{~s}$ rDNA. This species specific system was then applied directly to clinical specimens to identify infection with either Ps aeruginosa or Ps (Burkholderia) cepacia.

\section{Methods}

The type strains Ps aeruginosa NCTC 10332, Ps aeruginosa NCTC 10662, Ps (Burkholderia) cepacia NCTC 10661, and Ps (Burkholderia) cepacia NCTC 10744 were obtained from the National Type Culture Collection (Colindale, London). Two other strains of Ps aeruginosa (PA 01 and PA $01161)$ were used as well as one strain of $P s$ putida (P2440).

\section{EXTRACTION OF rRNA}

Cells were grown overnight in $100 \mathrm{ml}$ of L-broth at $37^{\circ} \mathrm{C}$ and then centrifuged at $5000 \times g$ at $4^{\circ} \mathrm{C}$ for 15 minutes. The resulting pellet was resuspended in $1 \mathrm{ml}$ of TE buffer ( $\mathrm{pH} \mathrm{8.0)}$ (TE buffer is $10 \mathrm{mM}$ TRIS$\mathrm{HCl}, 1 \mathrm{mM}$ EDTA, pH 8.0). Lysis buffer ${ }^{18}$ (5M guanidium thiocyanate, $10 \mathrm{mM}$ EDTA, $50 \mathrm{mM}$ TRIS-HCl (pH 8.0), 0.5\% sarkosyl, $8 \%$ mercaptoethanol) was added to give a final volume of $10 \mathrm{ml}$ and the mixture was then vortexed and left at room temperature for 10 minutes to complete cell lysis.

Two chloroform extractions were performed. Nucleic acids in the aqueous phase were precipitated on ice for 15 minutes with an equal volume of isopropanol and $2.5 \mathrm{M}$ ammonium acetate. After centrifugation at $6000 \times g$ at $4^{\circ} \mathrm{C}$ for 20 minutes, the pellet was dried and then resuspended in $700 \mu \mathrm{l}$ of TRIS-HCl (pH 7.6). DNase $1(5 \mu \mathrm{l})$ and $5 \mu \mathrm{l}$ of $1 \mathrm{M}$ magnesium-chloride were added and incubated at $37^{\circ} \mathrm{C}$ for 15 minutes.

One phenol and two chloroform extractions were performed. The RNA in the aqueous phase was precipitated on ice for 15 minutes with an equal volume of isopropanol and $2.5 \mathrm{M}$ ammonium acetate. After centrifugation for 5 minutes at $8000 \times g$ the pellet was dried in vacuo and then redissolved in water at a concentration of $3 \mathrm{mg} / \mathrm{ml}$ and stored at $-20^{\circ} \mathrm{C}$.

\section{SEQUENCING REACTION}

The sequencing protocol was a modification of the dideoxynucleotide terminated chain elongation method. ${ }^{19}$ The primers targeted at the conserved regions of the 16s rRNA were those which have been described before. ${ }^{19} 20$

Oligodeoxynucleotide probes and PCR primers were synthesised on an Applied Biosystems 380B synthesiser using phosphoramidite chemistry. No further purification was performed.

\section{AMPLIFICATION PROCEDURE}

A single bacterial colony was suspended in $1 \mathrm{ml}$ of phosphate buffered saline ( $\mathrm{pH} 7 \cdot 0$ ) and centrifuged at $8000 \times g$ for 10 minutes. The resulting pellet was resuspended in $20 \mu \mathrm{l}$ of lysis buffer $(1 \times$ PCR buffer, $0.5 \%$ Tween $20,200 \mu \mathrm{g} / \mathrm{ml}$ proteinase $\mathrm{K}$ ). The mixture was incubated at $55^{\circ} \mathrm{C}$ for 1 hour and then heated to $95^{\circ} \mathrm{C}$ for 10 minutes to inactivate the proteinase $K$. This reaction $(10 \mu \mathrm{l})$ was used for PCR without further purification. This was mixed with $9 \mu \mathrm{l}$ of $10 \times$ PCR buffer (200 mM TRIS-HCl (pH 8.3), $20 \mathrm{mM} \mathrm{MgCl}, 250 \mathrm{mM} \mathrm{KCl}, 0.5 \%$ Tween $20,1 \mathrm{mg} / \mathrm{ml}$ nuclease free bovine serum albumin), PCR primers (final concentration $0.25 \mu \mathrm{mol}$ each), deoxynucleoside triphosphates (final concentration $200 \mu \mathrm{mol}$ each), and 2.5 units $T a q$ polymerase (New Biologicals Limited, Hatfield, UK) per $100 \mu \mathrm{l}$ reaction. All the reagents except the cell lysis product and the Taq polymerase were mixed together and exposed to an ultraviolet transilluminator for 15 minutes to destroy any contaminating DNA. ${ }^{21}$ The cell lysis product was then added and cycling started. The mixture was initially denatured at $96^{\circ} \mathrm{C}$ for 5 minutes and then the Taq polymerase was added. Twenty-five cycles were performed as follows: denature $96^{\circ} \mathrm{C}$ for 15 seconds; anneal $52^{\circ} \mathrm{C}$ for 30 seconds; extend $70^{\circ} \mathrm{C}$ for 1.5 minutes. A final extension of 5 minutes at $70^{\circ} \mathrm{C}$ was performed. Following PCR, $10 \mu \mathrm{l}$ of the product was electrophoresed on a $1 \%$ agarose gel stained with ethidium bromide and viewed on an ultraviolet transilluminator.

\section{DOT BLOT HYBRIDISATIONS}

Species specific oligonucleotide probes were labelled at the $5^{\prime}$ ends with $\left[{ }^{32} \mathrm{P}\right] \mathrm{ATP}$ using T4 polynucleotide kinase (BRL). ${ }^{22}$ The PCR product $(10 \mu \mathrm{l})$ was blotted on to a nylon membrane (Hybond-N+, Amersham) using a slot blotter (Biorad). The DNA was denatured and alkali fixed according to the manufacturers' instructions. The membrane was then prehybridised for 1 hour at $42^{\circ} \mathrm{C}$ in $6 \times \operatorname{SSC}(20 \times \operatorname{SSC}$ is $3 \mathrm{M}$ sodium chloride and $0.3 \mathrm{M}$ sodium citrate), $5 \times$ Denhardt's solution $(100 \times$ Denhardt's solution contains $2 \%$ Ficoll, $2 \%$ polyvinyl pyrrolidone, and $2 \%$ bovine serum albumin), $0.5 \%$ sodium dodecyl sulphate (SDS), and $100 \mu \mathrm{g} / \mathrm{ml}$ salmon sperm DNA. Labelled probe with an activity of $10^{8}-10^{9} \mathrm{cpm} / \mu \mathrm{g}$ was added to the reaction mixture and incubated with shaking at $42^{\circ} \mathrm{C}$ for 4 hours. The membrane was washed twice in $2 \times \mathrm{SSC} / 0 \cdot 1 \% \mathrm{SDS}$ for 20 minutes each at $42^{\circ} \mathrm{C}$ and then in $0.1 \times \mathrm{SSC} / 0.1 \% \mathrm{SDS}$ for 20 minutes also at $42^{\circ} \mathrm{C}$. The slot blot was autoradiographed on X-Omat $S$ film (Kodak) at $-70^{\circ} \mathrm{C}$ for 24 hours.

\section{COLONY BLOT HYBRIDISATIONS}

These were performed on laboratory cultures of Ps aeruginosa, Ps (Burkholderia) cepacia, and $P s$ putida. The organisms were grown on L-agar at $37^{\circ} \mathrm{C}$ for 6 hours and then transferred on to a nylon membrane (Gene Screen; Dupont, NEN Research Products). The membrane was treated with sodium hydroxide and then neutralised according to the manufacturer's instructions, and the 
DNA fixed by drying at room temperature. Hybridisation was performed as described above.

\section{CLINICAL SAMPLES}

Sputum samples from patients with a range of respiratory disorders, including cystic fibrosis, were collected directly from the Public Health Laboratory (PHLS) at Leicester Royal Infirmary. Sputum $(0.5 \mathrm{ml})$ was removed into a separate container before the sample underwent any processing. All the samples were screened by the PHLS for PS aeruginosa and Ps (Burkholderia) cepacia using selective media. ${ }^{8}$ The sputum specimens for PCR were solubilised by adding an equal volume of dithiothreitol $100 \mu \mathrm{g} / \mathrm{ml}$ in sodium phosphate buffer $(\mathrm{pH} 7 \cdot 0)$. This mixture $(100 \mu \mathrm{l})$ was centrifuged for 5 minutes, the resulting pellet resuspended in $200 \mu \mathrm{l}$ of cell lysis buffer, and lysed as described above. This cell lysis product $(20 \mu \mathrm{l})$ was used for each PCR reaction without further purification. Dot blot hybridisation of sputum PCR products was performed as described above.

\section{Results}

SEQUENCE ANALYSIS

About 1000 bases of sequence were obtained for the strains of $P s$ aeruginosa, $P_{S}$ (Burkholderia) cepacia, and Ps putida. These sequences were aligned with published $16 \mathrm{~s}$ rRNA sequences for $P s$ aeruginos $a^{23}$ and Escherichia coli, allowing the identification of variable regions interspersed among conserved regions. At one site (640) the sequence of $P S$ aeruginosa differed from that of $P S$ (Burkholderia) cepacia by 10 bases (table 1). A computer search of Gen Bank and the European data base (European Molecular Biology Laboratory) showed that the 17 base segment containing this variable region did not match any previously reported rRNA sequence. Oligonucleotide probes specific to either Ps aeruginosa (PA 640) or Ps (Burkholderia) cepacia (PC 640) were synthesised to complement this variable sequence (table 2). Two other variable sites on the 16s rRNA sequences were chosen for the synthesis of complementary PCR primers specific for either Ps aeruginosa or Ps (Burkholderia) cepacia. Primers PA 1250 and PC 1250 were 17 bases long with three bases difference between Ps aeruginosa and Ps (Burkholderia) cepacia (table 3), whereas primers PA 480

Table 1 Alignment of $16 \mathrm{~s} r \mathrm{RNA}$ sequences at the probe site (640)

\begin{tabular}{lllll}
\hline Organism & $3^{\prime}$ & Sequence & & $5^{\prime}$ \\
\hline E coli & AUCUG & AUACU & GGCAA & GCU \\
Parn16s & UCCAA & AAGCU & ACUGA & GCU \\
P2440 & UCCAA & AANCU & GGCAA & GCU \\
PA 01 & Uccaa & AANCU & acuga & GCU \\
PL1017 & UccNa & AANCU & acuNa & GCN \\
PA01161 & Uccaa & AANCU & acuga & GCU \\
PA10332 & Uccaa & AANCU & acuga & GCU \\
PC10661 & Uaggu & AAACU & ggcag & GCU \\
PC10744 & Uaggu & AAACU & ggcag & GCU
\end{tabular}

Sites where sequences differ between $P_{s}$ aeruginosa and $P_{S}$ (Burkholderia) cepacia are indicated by lower case letters.
Table 2 Sequences of oligonucleotide probes and primers used in species specific PCR and DNA hybridisation

\begin{tabular}{lllll}
\hline Oligonucleotide & $5^{\prime}$ & Sequence & & $3^{\prime}$ \\
\hline PA 640 & AGCtc & agtAG & cTTtt & ggA \\
PC 640 & AGCct & gccAG & tTTac & ctA \\
PA 1240 & tTGTa & CCGAC & CATTG & TAG \\
PC 1240 & cTGTt & CCGAC & CATTG & TAt \\
PA 480 & GtTAC & CaacA & GAATA & AGC \\
PC 480 & GgTAC & CggaA & GAATA & AGC \\
\hline
\end{tabular}

Sites where sequences differ between $P_{S}$ aeruginosa and $P_{S}$ (Burkholderia) cepacia are indicated by lower case letters.

Table 3 Alignment of $16 s$ rRNA sequences at PCR primer site 1250

\begin{tabular}{lllll}
\hline Organism & $3^{\prime}$ & Sequence & & $5^{\prime}$ \\
\hline E coli & CUACA & AUGGC & GCAUA & CAA \\
Parn16S & CUACA & AUGGU & CGGUA & CAA \\
P2440 & CUACA & AUNGU & CGGUA & CAG \\
PA 01 & CUACA & AUNGU & CGGuA & CAa \\
PL1017 & CUACA & AUNGU & CGGuA & CAa \\
PA01161 & CUACA & AUNGU & CGGuA & CAa \\
PA10332 & CUACN & AUNGU & CGGuA & CNa \\
PC10661 & aUACA & AUGGA & CGGaA & CAg \\
PC10744 & aUACA & AUGGU & CGGaA & CAg \\
\hline
\end{tabular}

Sites where sequences differ between $P_{S}$ aeruginosa and $P_{S}$ (Burkholderia) cepacia are indicated by lower case letters.

and PC 480 had four out of 17 bases which differed (table 4). The PCR primers were matched for $\mathrm{G}+\mathrm{C}$ content and dissociation temperature.

AMPLIFICATION

Initially amplification was performed using one "universal" primer and one "species specific" primer. The universal primer (P536: ${ }^{5}$ CAGCA GCCGC GGTAA TAC ${ }^{3^{\prime}}$ ) was synthesised from a sequencing primer complementary to a universal region of the $16 \mathrm{~s}$ rRNA and was therefore appropriate for the amplification of $16 \mathrm{~s}$ rRNA from all bacteria. ${ }^{19}$ The second primer was 714 bases downstream from the first primer and was specific for either Ps aeruginosa or Ps (Burkholderia) cepacia as described above (PA 1250 and PC 1250). PCR was also subsequently performed using paired species specific primers (PA 480 and PA 1250, PC 480 and PC 1250) to amplify a segment of 16 sDNA 770 bases long.

When the PCR products from cultures of Ps aeruginosa, Ps (Burkholderia) cepacia, and Ps putida were visualised on agarose gels, there were no amplification products visible when Ps (Burkholderia) cepacia and Ps putida were amplified with the Ps aeruginosa primer and vice versa (fig 1). PCR was also

Table 4 Alignment of $16 \mathrm{~s} r \mathrm{RNA}$ sequences at PCR primer site 480

\begin{tabular}{lllll}
\hline Organism & $3^{\prime}$ & Sequence & & $5^{\prime}$ \\
\hline E coli & GTTAC & CCGCA & GAAGA & AGC \\
Parn16s & GTTAC & CAACA & GAATA & AGC \\
P2440 & GUUAC & CNGCN & GAAUA & AGC \\
PA01 & GuUAC & CaacA & GAAUA & AGC \\
PL1017 & GuUAC & CaacA & GAAUA & AGC \\
PA01161 & GuUAC & CaacA & GAAUA & AGC \\
PA10332 & GuUAC & CaacA & GAAUA & AGC \\
PC10661 & GgUAC & CggaA & GAAUA & AGC \\
PC10744 & GgUAC & CggaA & GAAUA & AGC \\
\hline
\end{tabular}

Sites where sequences differ between $P_{S}$ aeruginosa and $P_{S}$ (Burkholderia) cepacia are indicated by lower case letters. 


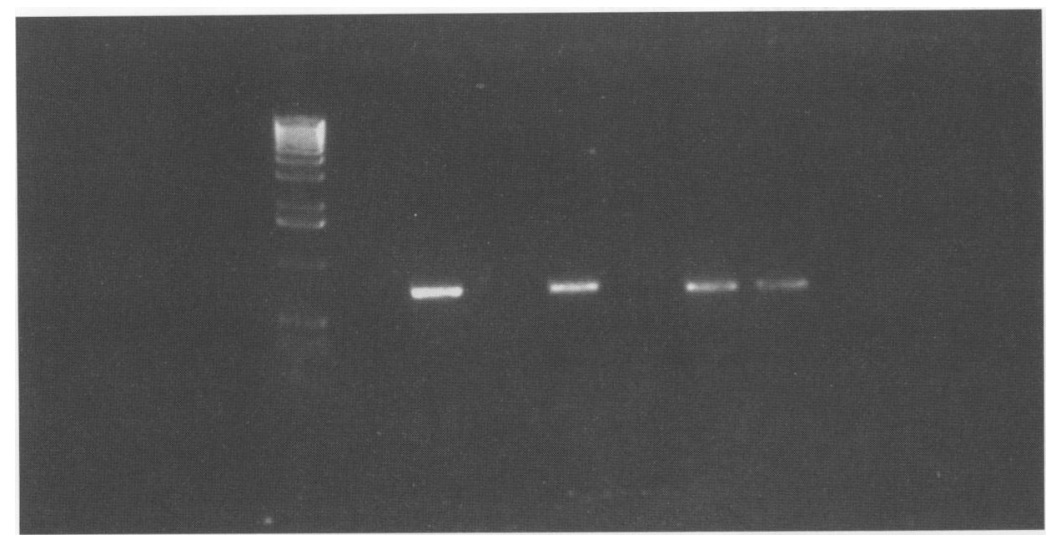

Figure 1 Species specific PCR: agarose gel electrophoresis of nucleic acid amplification products from cultures of Ps aeruginosa and Ps (Burkholderia) cepacia after amplification using primers as described. Lane 1: 1 kilobase DNA ladder (Bethesda Research

Laboratories); lane 2: negative control; lane 3: Ps aeruginosa amplified with P536 and PA 1250; lane 4: Ps (Burkholderia) cepacia amplified with P536 and PA 1250; lane 5: Ps (Burkholderia) cepacia amplified with P536 and PC 1250; lane 6: Ps aeruginosa amplified with P536 and PC 1250; lane 7: Ps aeriginosa positive control; lane 8: Ps (Burkholderia) cepacia positive control.

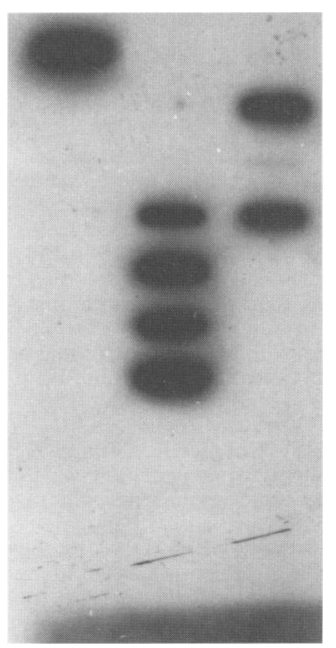

Figure 2 Hybridisation of PCR products: autoradiograph of sputum PCR products amplified with primers P536 and $P A 1250$ after hybridisation with the ${ }^{32} P$-labelled oligonucleotide specific for $P$ s aeruginosa (PA 640). Lane 1: positive and negative controls; lanes 2 and 3 each contain seven sputum PCR products. performed on pure cultures of Haemophilus influenzae, Streptococcus pneumoniae, Escherichia coli, Proteus vulgaris, and Klebsiella pneumoniae, using all sets of PCR primers described. No PCR products were visible on agarose gels.

\section{SPECIES SPECIFIC HYBRIDISATION}

The sequence target for the species specific within the region amplified by the PCR reaction. The specificity of the probes was confirmed by colony blot hybridisations with $P S$ aeruginosa, Ps (Burkholderia) cepacia, and Ps putida using the conditions described. The probes were species specific when hybridised with both the colony blots and the PCR products from the amplification of Ps aeruginosa and Ps (Burkholderia) cepacia. The presence of a large amount of high copy number DNA, following PCR, results in a strong hybridisation signal and therefore short autoradiography times as well as easy differentiation of positive and negative reactions (fig 2 ). When $10 \mu \mathrm{l}$ of PCR product were loaded on to an agarose gel an amplification band was just visible for $10^{2}$ cells $/ \mathrm{ml}$, but hybridisation of $10 \mu \mathrm{l}$ of PCR product gave a positive signal down to a concentration of 10 cells $/ \mathrm{ml}$ in the original sample.

\section{DETECTION OF pseudomonas SPP IN CLINICAL SAMPLES}

The system of species specific PCR and DNA hybridisation described was applied to sputum samples from patients with a range of respiratory conditions, including cystic fibrosis, and the results compared with conventional culture. Consecutive samples $(n=100)$ from the Public Health Laboratory at Leicester Royal Infirmary were tested. None was culture positive for Ps (Burkholderia) cepacia, but 10 were culture positive for $P_{s}$ aeruginosa. Sixty samples from patients with cystic fibrosis were tested for the presence of $P s$ aeruginosa and 60 for the presence of $P_{S}$ (Burkholderia) cepacia. There was full concordance of the results obtained from conprobes PA 640 and PC 640 was included
Table 5 Results of species specific PCR and DNA hybridisation applied to clinical samples

\begin{tabular}{lll}
\hline & $\begin{array}{l}\text { PHLS } \\
\text { samples }\end{array}$ & $\begin{array}{l}\text { Patients } \\
\text { with cystic } \\
\text { fibrosis }\end{array}$ \\
\hline $\begin{array}{l}\text { Ps aeruginosa } \\
\text { culture + ve }\end{array}$ & 10 & 27 \\
$\begin{array}{l}\text { Ps aeruginosa } \\
\text { PCR/probe + ve }\end{array}$ & 10 & 27 \\
$\begin{array}{l}\text { Ps aeruginosa } \\
\text { culture -ve }\end{array}$ & 90 & 33 \\
$\begin{array}{l}\text { Ps aeruginosa } \\
\text { PCR/probe -ve }\end{array}$ & 90 & 33 \\
$\begin{array}{l}\text { Ps cepacia } \\
\text { culture + ve }\end{array}$ & 0 & 16 \\
$\begin{array}{l}\text { Ps cepacia } \\
\text { PCR/probe + ve }\end{array}$ & 0 & 16 \\
$\begin{array}{l}\text { Ps cepacia } \\
\text { culture -ve }\end{array}$ & 100 & 44 \\
Ps cepacia & 100 & 44 \\
PCR/probe -ve & & \\
\hline
\end{tabular}

ventional culture with those from combined PCR and DNA hybridisation, with $100 \%$ specificity for both $P s$ aeruginosa and $P s$ (Burkholderia) cepacia (table 5).

When PCR was performed directly on sputum samples and the results analysed on an agarose gel, an amplification product of the correct size was sometimes visible even when conventional culture had not revealed any infection with Ps aeruginosa or Ps (Burkholderia) cepacia (fig 3). The hybridisation reaction was accurate and species specific as these non-specific PCR products did not hybridise with the species specific probes confirming the absence of both Ps aeruginosa and Ps (Burkholderia) cepacia in the original sputum sample. These inappropriate PCR products occurred even when the "universal" primer was replaced by a second species specific primer (PA 480 or PC 480), and they were not affected by manipulating the PCR reaction to increase its specificity-that is, by changing the magnesium concentration of the PCR buffer or the annealing temperature of the PCR primers. There was no association between the appearance of these amplification products and a specific bacterial species on conventional culture. These observations suggest that inappropriate priming of bacterial or human DNA was occurring in the PCR reaction which may have been eliminated by further purification of the sputum samples prior to PCR, but this would increase laboratory time and involve the use of potentially hazardous chemicals such as phenol.

\section{Discussion}

These results show that a species specific system of PCR and DNA hybridisation based on 16s RNA sequences is applicable in clinical practice. Although it would be possible to amplify DNA from all bacteria in a clinical sample using PCR primers from universal regions of the 16sRNA, a species specific system improves the relative strength of the positive signal in the subsequent hybridisation reaction. The whole process of sputum preparation, PCR, and DNA hybridisation can be performed within a day, with the autoradiography result ready the next day. 


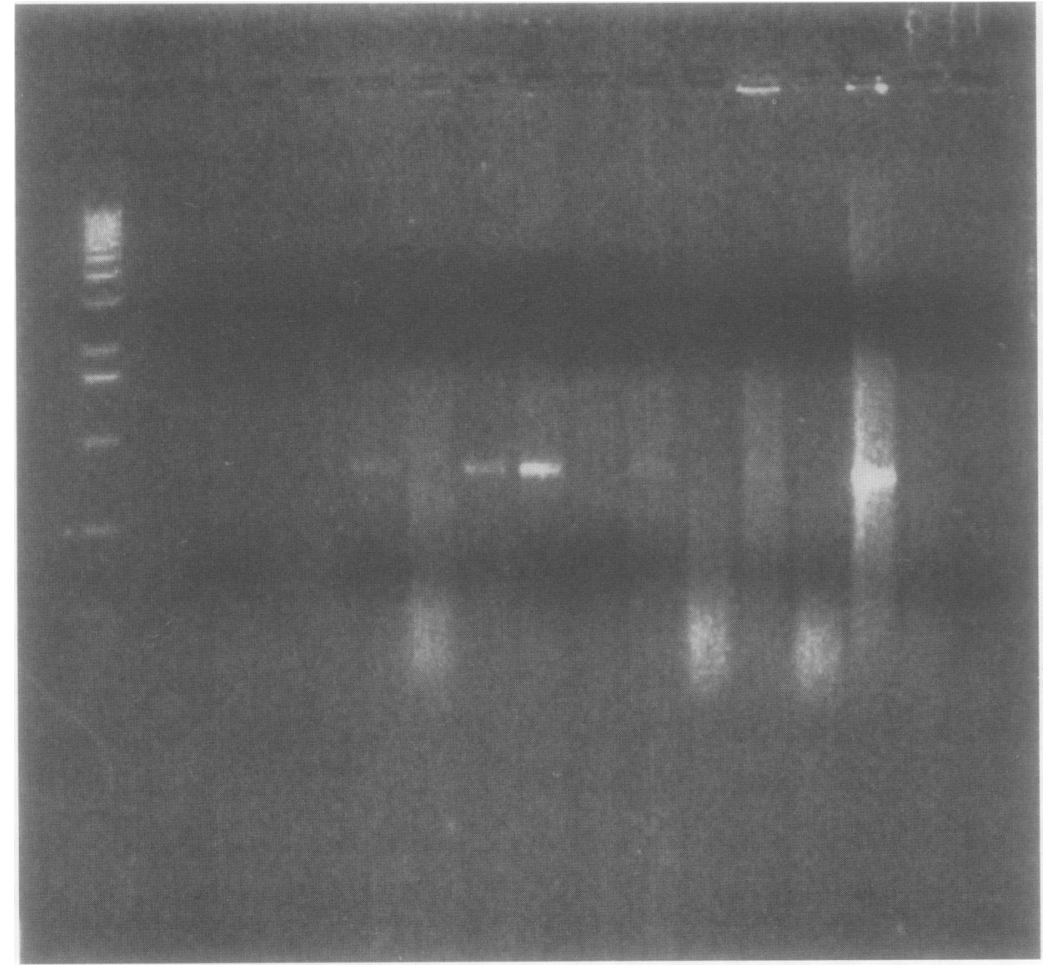

Figure 3 Non-specific sputum PCR products: agarose gel electrophoresis of nucleic acid amplification products from sputum after PCR amplification with primers $P A 480$ and

PA 1250. Lane 1: 1 kilobase DNA ladder (Bethesda Research Laboratories); lanes 2 to 14: sputum PCR products; lane 15: positive control; lane 16: negative control. Only lanes 7, 8, and 15 had positive results after hybridisation with the Ps aeruginosa specific oligonucleotide probe.
2 Brett M, Ghoneim A, Littlewood J. Serum IgA antibodies against Pseudomonas aeruginosa in cystic fibrosis. Arch Dis Child 1990;65:259-63.

3 Simmonds EJ, Conway SP, Ghoneim ATM, Ross H, Littlewood JM. Pseudomonas cepacia: a new pathogen in patients with cystic fibrosis referred to a large centre in patients with cystic fibrosis referred to a large centre 4 Gladman G, Connor PJ, Williams RF, David TJ.

Gladman G, Connor PJ, Williams RF, David TJ. Pseudomonas maltophilia in cystic fibrosis. Arch Dis Child 1992;67:192-5.

5 Isles A, Maclusky I, Corey M, et al. Pseudomonas cepacia infection in cystic fibrosis: an emerging problem. $f$ Pediatr 1984;104:206-10.

6 Thomassen MJ, Demko CA, Klinger JD, Stern RC. Pseudomonas cepacia colonisation among patients with cystic fibrosis. A new opportunist. Am Rev Respir Dis 1985;131:791-6.

7 Tablan OC, Martone WJ, Doershuk CE, et al. Colonisation of the respiratory tract with Pseudomonas colonisation of the respiratory tract with Pseudomonas Chest 1987;91:527-32.

8 Tablan OC, Carson LA, Cusick LB, Bland LA, Martone WJ, Jarvis WR. Laboratory proficiency test results on use of selective media for isolating Pseudomonas cepacia from simulated sputum specimens of patients with cystic fibrosis. F Clin Microbiol 1987;25:485-7.

9 Gilligan PH, Gage PA, Bradshaw LM, Schidlow DV, DeCiccio BT. Isolation medium for the recovery of Pseudomonas cepacia from respiratory secretions of patients with cystic fibrosis. F Clin Microbiol 1985; 22:5-8.

10 Woese CR. Bacterial evolution. Microbiol Rev 1987; 51:221-12.

11 Gobel UB, Geiser A, Stanbridge EJ. Oligonucleotide probes complementary to variable regions of ribosomal RNA discriminate between mycoplasma species. $\mathcal{f} \mathrm{Gen}$ Microbiol 1987;133:1969-74.

12 Boddinghaus B, Rogall T, Flohr T, Blocker H, Bottger EC. Detection and identification of Mycobacteria by amplification of rRNA. $尹$ Clin Microbiol 1990 28:1751-9.

13 Wilson $\mathrm{KH}$, Blitchington $\mathrm{R}$, Shah $\mathrm{P}$, McDonald G, Gilmore RD, Mallavia LP. Probe directed at a segment of Rickettsia ricketsii rRNA amplified with PCR. ₹ Clin Microbiol 1989;27:2692-6.

14 Wilson KH, Blitchington R, Hindenach B, Greene RC Species-specific oligonucleotide probes for rRNA of Clostridium difficile and related species. $\mathcal{f}$ Clin Microbio 1988;26:2484-8.

To improve the application of this system the labelling of the oligonucleotides should ideally be non-radioactive. Biotin labelling was unsuccessful because of false positive reactions due to non-specific binding of the streptavidin molecules to cellular debris in colony blots as well as in clinical samples after PCR. Previous studies have also shown that the clarity of the positive signal obtained with radiolabelled probes is superior to that from biotinylated probes. ${ }^{24}$

In summary, we have developed a system of PCR and DNA hybridisation for the identification of infection with $P s$ aeruginosa and Ps (Burkholderia) cepacia in sputum. Further studies are needed to combine this technique with the detection of serum IgA antibodies specific for $P$ s aeruginosa to determine whether increased antibody titres are a sign of early infection with small numbers of organisms in the respiratory tract of patients with cystic fibrosis.

EM O'Callaghan was an Action Research Training Fellow.

1 Mearns MB, Hunt GH, Rushworth R. Bacterial flora of respiratory tract in patients with cystic fibrosis, respiratory tract in patients with cystic
15 Giovannoni SJ, DeLong EF, Olsen GJ, Pace NR Phylogenetic group-specific oligodeoxynucleotide probes for identification of single microbial cells. $\mathcal{F}$ Bacteriol 1988;170:720-6.

16 Shawar RH, El-Zaatari FAK, Nataraj A, Clarridge JE Detection of Mycobacterium tuberculosis in clinical topic hybridisation methods. $¥$ Clin Microbiol 1993;31:61-5.

17 Wilson KH, Blitchington RB, Greene RC. Amplification of bacterial 16s ribosomal DNA with polymerase chain reaction. $¥$ Clin Microbiol 1990;28:1942-6.

18 Cathala G, Savouret J, Mendez B, et al. A method for isolation of intact, transitionally active ribonucleic acid. DNA 1983;2:329-35.

19 Lane DJ, Pace B, Olsen GJ, Stahl DA, Sogin ML, Pace NR. Rapid determination of $16 \mathrm{~s}$ ribosomal RNA sequences for phylogenetic analyses. Proc Natl Acad Sci USA 1985;82:6955-9.

20 Embley T, Smida J, Stackebrandt E. Reverse transcriptase sequencing of $16 \mathrm{~s}$ ribosomal RNA gene from Faenia sequencing of 16s tibosomal RNA gene from Faenia rectivirgula, Pseudonocardia thermophia and Saccharopolyspora hirsuta, three wen Microbiol 1988;134: which

21 Sarkar G, Sommer S. Shedding light on PCR contamination. Nature 1990;343:27.

22 Sambrook J, Fritsch EF, Maniatis T. Molecular cloning: laboratory manual. 2nd edn. Cold Spring Harbor, New York: Cold Spring Harbor Laboratory Press, 1989: 31-2.

23 Toschka H, Hopfl P, Ludwig W, Schleifer K, Ulbrich N, ribosomal RNA gene from Pseudomonas aeruginosa. Nucleic Acids Res 1988;16:2348.

24 Malowin F, Bryan LE, Shewciw P, et al. DNA probe technology for rapid detection of Haemophilus influentechnology in clinical specimens. I Clin Microbiol 1988;26: $2132-8$. samples by two polymerase chain reaction and non-isoErdmann V. Complete nucleotide sequence of a $16 \mathrm{~s}$ 